\title{
MEASUREMENT OF BRAND EQUITY AND A SURVEY IN THE BANKING SECTOR
}

\author{
T. Sabri ERDIL \\ Ufuk AYDIN \\ Marmara University, Turkey
}

\begin{abstract}
This study explores how consumers evaluate brand names of a selected group of banks using the consumerbased brand equity measurement. We conceptualise brand equity as a four dimensional construct comprising consumer awareness, brand image, perceived product/service attributes and customer relationship and communication characteristics. The perceptions of customers about social responsibility activities of banks have also been included. The findings indicate that brand image characteristics have been found to be more important than product/service attributes for the selected sample of banks. Brand image characteristics such as prestige and a good reputation is likely to be most influential in building brand equity followed by product/service quality which has been ranked second by respondants.
\end{abstract}

Key Words: Brand equity, brand awareness, banking industry, measurement, customer perception.

\section{INTRODUCTION}

In recent years, firms have invested substantial resources to develop names with a favorable image. The brand name is regarded as an essential part of the brand and the foundation for marketing communication efforts (Aaker, 1992). Consumers attach additional value to products because of brand name carried by the product. This added value endowed by a brand name to a product is called brand equity (Pappu and Quester, 2006). Product introductions with the same brand name are able to leverage the brand image, brand aweraness, and on the whole, brand equity obtained in the established markets (Milberg et al, 1997; Salinas and Perez, 2008). Almost every marketing activity works to build, manage, and exploit brand equity (You and Donthu, 2001). Brand equity provides value to the firm by enhancing efficiency of marketing programs, prices, and profits, trade leverage, brand extension and competitive advantage (Aaker, 1990). Brands succeed by getting, keeping, and growing customers. The consumer-brand relationship, as an important research topic, will regard to acquiring new customers, customer retention and brand equity (Smith et al, 2007).

Several conceptualizations of brand equity exist, and these conceptualizations have offered valuable insight into the processes that consumers evaluate brands within a given product category (Netemeyer et al, 2004). This paper, first, briefly reviews the conceptualizations and measurements of brand equity. Then, the results of a survey conducted in the banking sector are given. Finally, a discussion with implications for future research is presented. 


\section{Conceptual Background}

Brand equity (BE) has been used as a barometer of brand strength through the use of its logo, symbol, or name (Morgan, 2000; Lee and Back, 2008). Aaker (1996) views brand equity as a set of assets linked to a brand's name and symbol that adds the value provided by a product/service to the customer. Brand equity is a function of several facets, the core facets are the primary predictors of brand purchase intent and behavior. Core BE facets include perceived quality, perceived value for the cost, uniqueness and the willingness to pay a price premium (Aaker, 1996; Netemeyer et al, 2004) that are the strongest predictor of purchase intent. Five related brand associations that are viewed as related to the core BE facets in brand equity frameworks are given as brand awareness, brand familiarity, brand popularity, organizational associations and brand-image consistency (Aaker, 1996; Keller, 1993).

Brand awareness is viewed as the degree to which consumers automatically think of a brand when a given product category is mentioned. Brand familiarity is defined as the degree to which consumers are familiar with the brand name. Organizational associations are those beliefs held by the consumer that the company is honest and trustworthy. Brandimage consistency is viewed as the degree to which consumers feel the band has a rich heritage (Netemeyer et al, 2004). These brand associations are important and their correlates of the core facets are examined in emprical studies. To a large extent, researchers conceptualized brand associations into four major dimensions: product or service quality, brand image, brand awareness and brand attitute (Kwun and $\mathrm{Oh}$, 2007). These associations are regarded as the category of a brand's assets and liabilities that include anything"linked " in memory to a brand (Aaker,1990).

Another conceptualization, based on Berry's study (2000) presents the principal components of a services organization brand: organization's presented brand, external brand communication, and customer experience with the organization. The presented brand is the organization-controlled communication of a desired brand image and it directly impacts brand awareness which is a customer's ability to recognise and recall a brand. External brand communication is the organization-influenced communication about the brand. Publicity and word-of-mouth are its main forms. Customer experience with the organization is customer's cumulative experience interacting with the organization (Berry and Seltman, 2007).

As can be seen, multidimensional constructs of brand associations are very similar to each other which makes understanding consumers'perceptions of brands complex. One important consensus among the approaches is that brand equity is the incremental value of a product due to the brand name (Yoo and Donthu, 2001).

\section{Measurement of Brand Equity}

Marketers desire to demonstrate that they are allocating marketing investments as efficiently as possible. One of the first endeavors to measure intangible assets specific to marketing is brand equity. Cultivating strong brands with high equity improves the profitability of brand choice, brand performance, cash flow, willingness to pay a premium, marketing productivity, product positioning and brand knowledge in consumers'minds (Kapferer, 2004; Lee and Back, 2008). One question here is whether brands truly are assets that enable the business to generate superior returns over time. Brand equity needs to be measured in a way that captures the source and scale of emotional augmentation that the brand provides underlying functionality of the product or service (Knowles, 2008).

Although most marketers are unsure how to measure brand equity and there is no universally agreed upon measure, they recognise that a brand's equity consists of different components which should be studied separately. There are two different approaches to measure the brand equity (Knowles, 2008). The first approach measures equity in terms of "outcomes" such as recommending the brand to others, the price premium they are prepared to pay. The second type of approach measures equity in terms of the scale and nature of the utility that the brand offers to customers. The second approach tries to quantify the extent of brand equity that a brand enjoys by measuring the degree of "relevant differentiation" provided. It measures two goals achieved-maximization of the perceived fit between your brand and your customer's need and the maximization of perceived differentiation of your brand versus its competitors.

Another conceptualization of measurement considers three main aspects of brand equity; the financial perspective, the customer-based perspective and the combined perspective. The operationalizations of customer-based brand equity can be divided into customer perception (e.g. brand awareness, perceived quality) and customer behavior (e.g. brand loyalty, willingness to pay a high price) (Keller,1993; Chen and Chang, 2008).

Of the different streams of research in brand equity, 
the consumer psychology and the financial approach have dominated. (Seggie et al, 2007). According to Aaker(1996) the measurement of brand equity can be undertaken using loyalty measures, perceived quality measures, associations/differentiation measures, and awareness measures (Seggie et al, 2007). The consumer psychology perspective acknowledges micro-level data as the measures are aggregated from individual customers, although the final measure itself is an aggregate brand-level measure. The financial approach to measuring brand equity pays more attention to objective measures such as profits stemming from the brand and thus estimating the firm's overall brand equity (Simon and Sullivan, 1993; Seggie et al, 2007).

\section{Research Model and Aim of the Study}

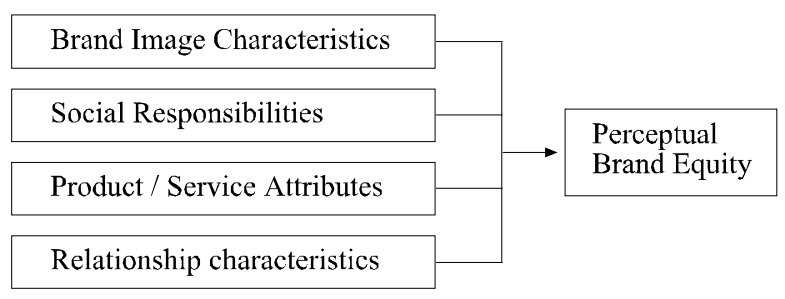

\section{Figure 1. Theoretical Model}

The aim of the study is to measure brand equity values of a sample of Turkish banks by using consumer perception model. In the survey, firstly, the recognition rates of brands in the banking sector have been analyzed. The framework used in the measurement was designed in three categories,"the top-of-the-mind aweraness" brands, "unaided brand recognition" brands, and lastly "aided brand recognition" brands.

The second phase of the survey included expectationperformance analysis which is a perceptual brand evaluation technique. The findings demonstrated perceptual brand equity values according to performance levels of brands in comparison with each other. It is proposed that highly valued brands by consumers are considered to be offering preferred services/products that may imply successful future results.

The respondants were firstly asked how important the items of institutional image characteristics, social responsibilities, product/service quality attributes and relationship management to them on a rating scale from 1 to 5 indicating importance level of each item. Then, the extent to which each bank has been found successful for each item was analyzed.

The survey results were presented by using expectationperformance maps designed both for each main dimension and for each item of dimensions seperately. Considering the "brand equity as the net present value of future cash inflows" (Doyle, 2003), perception maps will be helpful in identifying what products/services and characteristics of which brands will be preferred today and in future. The analysis also determines the sectoral average and the place of each brand in the sector.

\section{Research Framework and Measures}

The current study aims to examine how consumers evaluate brands and how individual member brands are perceived by the consumers. Some researchers have suggested the use of a relative measure for the measurement of brand equity (Pappu and Quester, 2006). One of the methods proposed under this approach involved the use of consumer preference ratings for a well-known branded product versus a less-known branded product (Aaker, 1996). Given the current branding conceptualizations, brand-specific association which is an attribute or benefit that differentiates a brand from competing brands is used in the current study. Brand associations facilitate consumers to process, organize, and retrieve information to assist them in making purchase decisions (Kwun and Oh, 2007). In the study, brand associations namely product/service quality, image, awareness and brand communication are used consistently with the literature.

Aaker (1996) asserts that perceived quality is a bottomline measure of the impact of a brand identity and reflects a measure of goodness of the brand. For the purpose of the current study overall service/product quality is measured by using a scale of nine items. A favorable reputation or image reflecting the overall perception of a bank brand has been considered a valuable competitive advantage for a firm, communicating effectively to its target groups about the quality of its services and products in a meaningful way. Consistent with the institutional view, corporate image can be defined as an overall evaluation reflecting the extent to which a firm is substantially 'good' or 'bad'(Weiss et al., 1999; Keh and Xie, 2008). Brand reputation is a stable construct that represents the distillation of multiple images over time (Kwun and $\mathrm{Oh}, 2007)$. Brand image is measured by a three items scale focusing on overall reputation and another three items scale for the evaluation of social responsibilities that maintains the brand image. Brand awareness is recognized as an important concept in consumer behavior, especially in terms of its implication to brand equity. One basic approach assessing brand awareness 
is brand recognition that relates to consumers' ability to recognize the brand when given the product category (Keller, 1993). This study focuses on the brand recognition aspect of brand awareness which is important in understanding the consumer decisionmaking process. The last dimension we included in the survey is customer relationship management. The focus has been on the customer and the external communication and a measurement scale of four-items is used.

Consumer perceptual brand evaluation technique is used in the analysis for the four dimensions of brand equity mentioned above. Expected and real performance levels of brands are mapped in comparison with each other. In the evaluation, expectation values are given on the horizontal axis and real performance levels on the vertical axis. A Likert-type scale of 1-5 was adopted for all measures using the anchors 'strongly disagree'(1) and 'strongly agree'(5). Within the framework of the analysis, four or five brands are considered one of which being the well-known and the other being the smaller but astill a known brand which is consistent with the Aaker's study (1996).

\section{Methodology and Data}

The data were gathered through a questionnaire form. The questions have been asked to people between age of 15 and 54 who have been involved in at least one individual banking transaction within the last mounth. Respondants were randomly selected with quoatiations of gender, age and education within the largest ten proviences of İstanbul. A sample of 272 respondants answering the questionnaire fully has been considered in the research. The questionnaire form includes the names (brands) of banks and their recognition immediately, spontaneously, by aid, and lastly in relative with benchmark banks.

In this study, expectation-performance analysis is used in order to evaluate customers' expected ideal value for the characteristics of brand perception in return to how these expectations are met with real performance of firms working in banking sector. When the shifts in product/service differences occur in invisible attributes rather than visible ones, the effectiveness of perceptual brand evaluation techniques will increase. The research has been conducted in banking sector where implementing a differentiation strategy in products/services seems to be highly difficult.

Four brands have been included as benchmarks in the analysis with the aim of making a comparison with the competitors and calculating brand value of the firm by considering its position in the sector and obtaining a sectoral average for brand value. Selection criteria will vary from one sector to another depending on the brands to be compared. One of the common methods is to choose the leading brand in the sector and the relatively smaller one which is known in the market only to some extent.

The sector leader, Türkiye İş Bankası with its 883 branches in Turkey, Finansbank whose $46 \%$ shares belonged to National Bank of Greece with a foreign partnership, Garanti Bankası, one of the top banks with its 354 branches nationwide and lastly, Oyakbank which is relatively smaller than other banks have been included in the research.

\section{Findings}

The first recognised brand name has been found to be Turkiye Iş Bankası with $79.8 \%$ without any aid. When recognition with aid is included, the total percentage of respondants who recognise the brand name increases to $100 \%$. In terms of first rememberance, İş Bankası is followed by Garanti Bankası, Akbank and Yapı Kredi Bankası with 53.3 $\%, 24.6 \%$ and $12.9 \%$ respectevely. When we consider other benchmark banks in the evaluation, the recognition rates of respondants have been found to be $5.5 \%$ for Finansbank and only $1.1 \%$ for Oyakbank.

The survey results indicated that spontaneous recognition rates of brand names of banks have been to be $53.3 \%$ for Garanti Bankası, $42.6 \%$ for Finasbank, and $16.9 \%$ for Oyakbank without any aid. Total unaided brand recognition of all these four brands has been found to be $100 \%$.

The results of expectation-performance evaluation results indicate that the highest expectation of respondants has been on "institutional image characteristics"(4.59) which is partly a surprising result for the banking sector. This is followed by product/service attributes (4.41), customer relationships (4.24) and social responsibilities (4.08) respectively.

'Institutional image characteristics' dimension including items such as "a highly-regarded and prestigious bank", "a well-estrablished and stable bank", "a trustful bank" has been given a higher importance than 'service/product quality' dimension which might be interesting for the banking sector by consumers. İs Bankası has been found the most successful bank for"Institutional image characteristics" with 4.45 out of five followed by Garanti Bankas1 with 3.76 .

For the four main measurement dimensions consisting 
Table 1: Recognition Rates in the Banking Firms

$\begin{array}{llllllllllllllllll}100 & 100 & 100 & 100 & 100 & 100 & 100 & 100 & 100 & 98,9 & 95,2 & 93,4 & 77,2 & 72,4 & 65,4 & 59,2 & 58,6 & 51,1\end{array}$

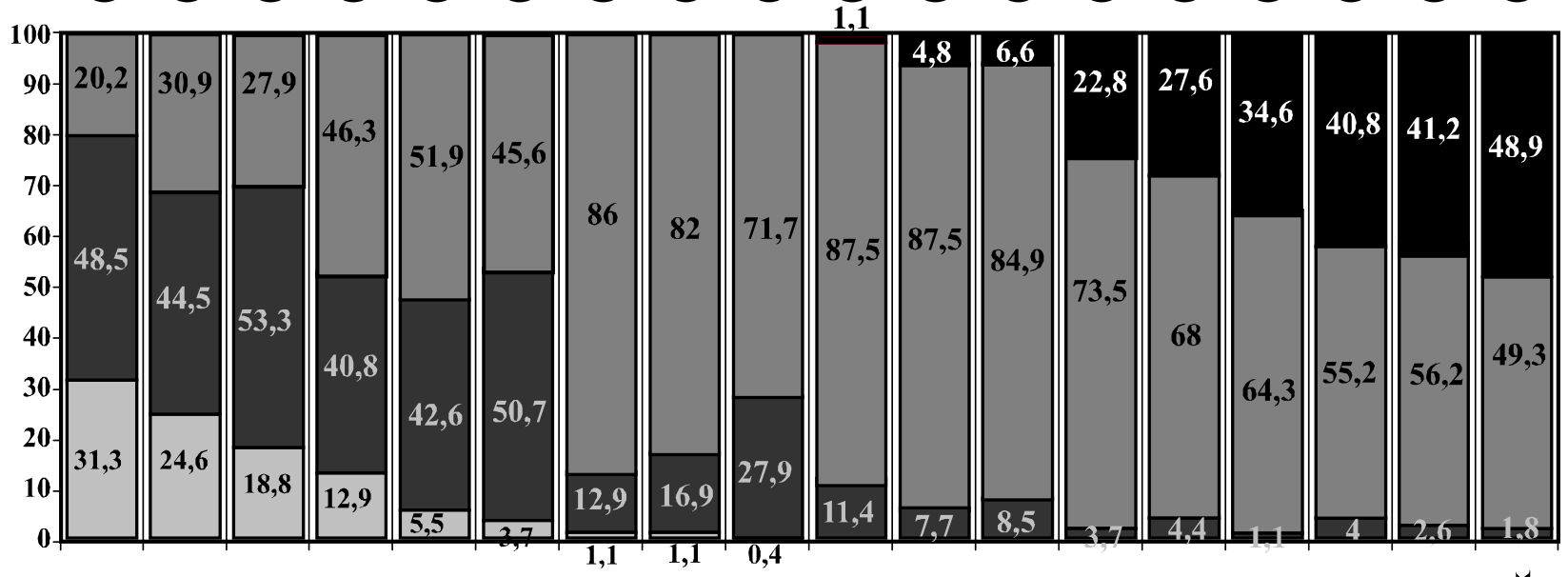

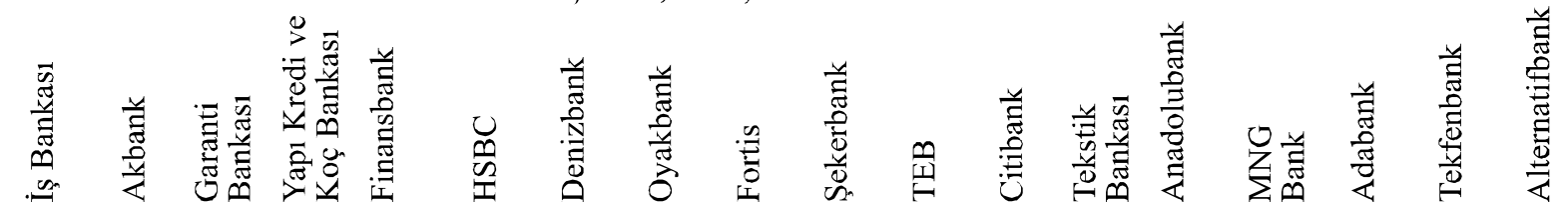

Top recognized

$>$ Spontenous rememberance
$>$ Aided rememberance

$>$ Never heard

Table 2: Expectation-Perceived Performance Results for Main Dimensions

\begin{tabular}{|l|r|r|r|r|r|}
\hline & EXPECTED & $\begin{array}{r}\text { FINANS } \\
\text { BANK }\end{array}$ & $\begin{array}{r}\text { GARANTI } \\
\text { BANKASI }\end{array}$ & $\begin{array}{r}\text { is } \\
\text { BANKASI }\end{array}$ & $\begin{array}{r}\text { OYAK } \\
\text { BANK }\end{array}$ \\
\hline Institutional & 4,59 & 3,20 & 3,76 & 4,45 & 3,09 \\
\hline Social Responsibility & 4,08 & 2,81 & 3,73 & 3,73 & 2,73 \\
\hline Product/Service Attributes & 4,41 & 3,21 & 3,81 & 3,81 & 2,78 \\
\hline Relationship Management & 4,24 & 3,26 & 3,72 & 3,72 & 2,88 \\
\hline Average & 4,33 & 3,12 & 3,93 & 3,93 & 2,87 \\
\hline
\end{tabular}

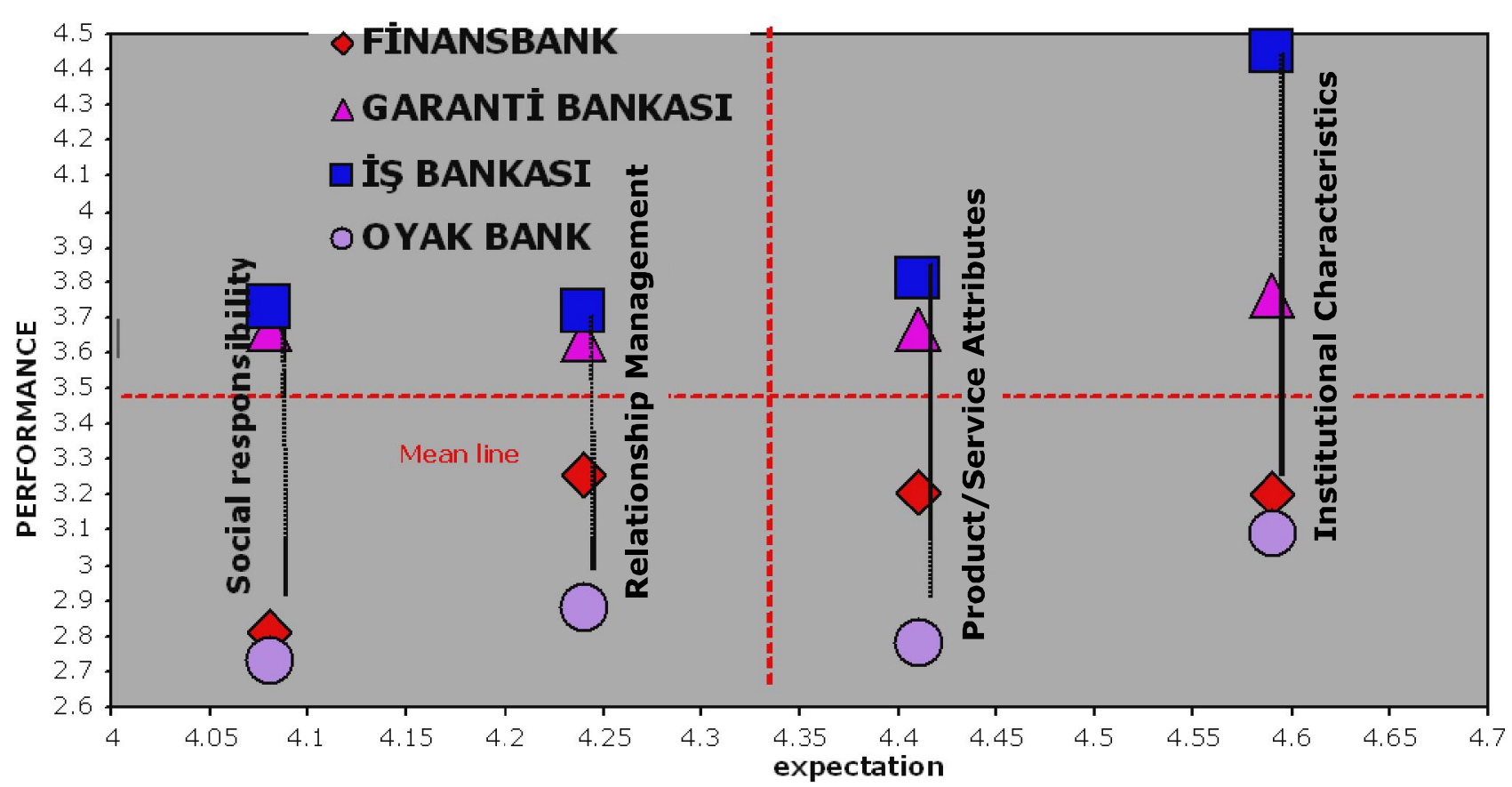


of 19 items, İș Bankası has been to have the highest overall perceptual brand value $(3,93)$, being the first, Garanti Bankasi the second $(3,69)$, Finansbank the third $(3,12)$, and Oyakbank the fourth $(2,87)$.

The data obtained from the research also gives the apportunity to make improvements in the poor performance high expectation service areas of banks. None of the banks has been able to meet the expectations of consumers fully in all 19 service items. The gap between the percepted actual performance and expected performance will give an idea of the field in which the banks should improve themselves.

For the product/quality dimension, 'having a wide network of ATM and branch offices' had the highest expected value $(4,75)$ followed very closely by 'giving fast and correct service'by consumers. İş Bankasi and Garanti Bankasi have been ranked as the first two banks for the product/service characteristics dimension with 3,81 and 3,67 respectively.

As for the items of bank image, consumer expectations focused mostly on how much the bank was trustable $(4,73)$. This item was followed by how much the bank was highly-regarded and prestigious $(4,55)$. Once more Is Bankas1 has been ranked the first for these two items.

Support for social activities such as environment, art and sports has been ranked first as expected social responsibility activities by consumers $(4,16)$. Among the consumer relations and communication items, the biggest expected value has been put on customer satisfaction and implementing solutions to customer problems with ratings of 4,65 and 4,60 respectively.

\section{CONCLUSIONS}

In the analysis, expectation/performance analysis which is one of the perceptual brand equity evaluation methods was used. This method seems to be an effective technique in determining the place of a brand in the industry and the positions of brands comparatively to each other. Although there is a tendency toward differentiation in products occuring more in the invisible and intangible characteristics of products/services than tangible ones, visible and tangible differentiations seem still to have greater influence in buying decisions of consumers. In the banking sector, for example, interest rates would give the opportunity to make differentiation in services/products, if the interest rates had not been determined by the Central Bank of Turkey.

Survey results indicate that among the banks in the analysis, İs Bankası obtained the highest recognition rate. $79.8 \%$ of respondents recognised İş Bankas1 spontaneously and unaidly. When aided recognition is added, $100 \%$ of repondants remembered İş Bankası. It was followed by Garanti Bankası and Akbank with the rememberance rates of $53.3 \%$ and $24.6 \%$ respectively.

Another finding is that "Institutional Characteristics" measured with three items such as reliability, stability, and prestige have been found to be more important than "product/service attributes" which might be a surprising result for the banking sector. This result may support the view that it is difficult to differentiate products/services in the banking sector whereas institutional characteristics such as prestige and a good reputation which are more invisible in nature, will create the value for the consumers. Customer perception of brand equity relies more on reputational characteristics than other dimensions such as service quality. This may stem from the rationale that banks require to establish effective product differentiation strategies and perceived quality should be managed carefully.

This study simply focused on consumer perceptions of brands in the banking sector. The link between brand equity and corporate performance was not included as a research question that should be surmounted in future research. Another limitation of the study is the sampling framework. This study was constrained to respondants from a single city, and this may limit generalizations. Also, the results of this study would be more representative if the research were conducted for a larger sample size. 


\section{APPENDIX}

Table 3. Expected and Perceived Performance Results for Institutional Image Characteristics

\begin{tabular}{|l|r|r|r|r|r|}
\hline & EXPECTED & $\begin{array}{r}\text { FINANS } \\
\text { BANK }\end{array}$ & $\begin{array}{r}\text { GARANTI } \\
\text { BANKASI }\end{array}$ & $\begin{array}{r}\text { İs } \\
\text { BANKASI }\end{array}$ & $\begin{array}{r}\text { OYAK } \\
\text { BANK }\end{array}$ \\
\hline A highly-regarded prestigious Bank & 4,55 & 3,25 & 3,81 & 4,35 & 3,05 \\
\hline Well-established and Stable & 4,49 & 2,03 & 3,67 & 4,45 & 2,98 \\
\hline Trustable & 4,73 & 3,33 & 3,80 & 4,53 & 3,26 \\
\hline Average & 4,59 & 3,20 & 3,76 & 4,45 & 3,09 \\
\hline
\end{tabular}

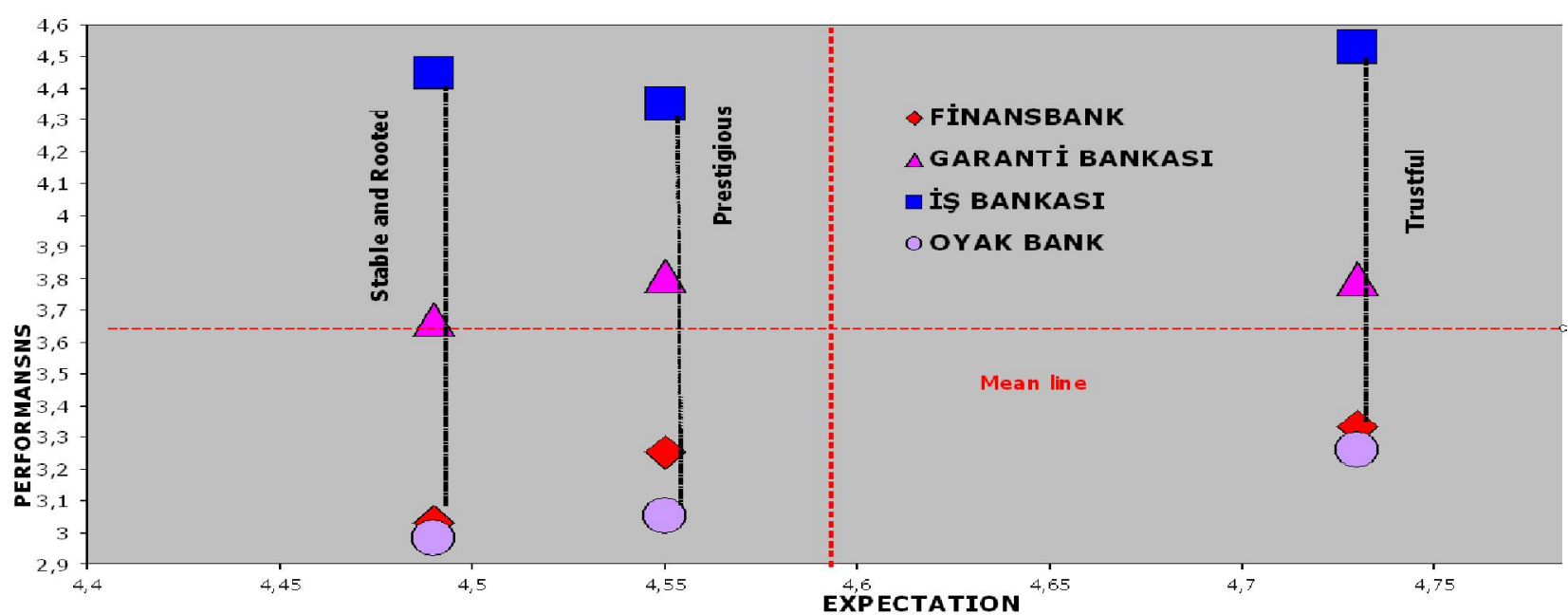

Figure 2. Institutional İmage Characteristics

Table 4. Figures for Social Responsibility Characteristics

\begin{tabular}{|l|r|r|r|r|r|}
\hline & EXPECTED & $\begin{array}{r}\text { FINNANS } \\
\text { BANK }\end{array}$ & $\begin{array}{r}\text { GARANTI } \\
\text { BANKASI }\end{array}$ & $\begin{array}{r}\text { İS } \\
\text { BANKASI }\end{array}$ & $\begin{array}{r}\text { OYAK } \\
\text { BANK }\end{array}$ \\
\hline Supports social activities & 4,16 & 2,57 & 3,76 & 3,79 & 2,63 \\
\hline $\begin{array}{l}\text { Involves in non-profit } \\
\text { organizations for public purposes }\end{array}$ & 4,11 & 2,62 & 3,42 & 3,48 & 2,65 \\
\hline Contributes to the sectoral development & 3,96 & 3,24 & 3,82 & 3,91 & 2,91 \\
\hline Average & 4,08 & 2,81 & 3,67 & 3,73 & 2,73 \\
\hline
\end{tabular}

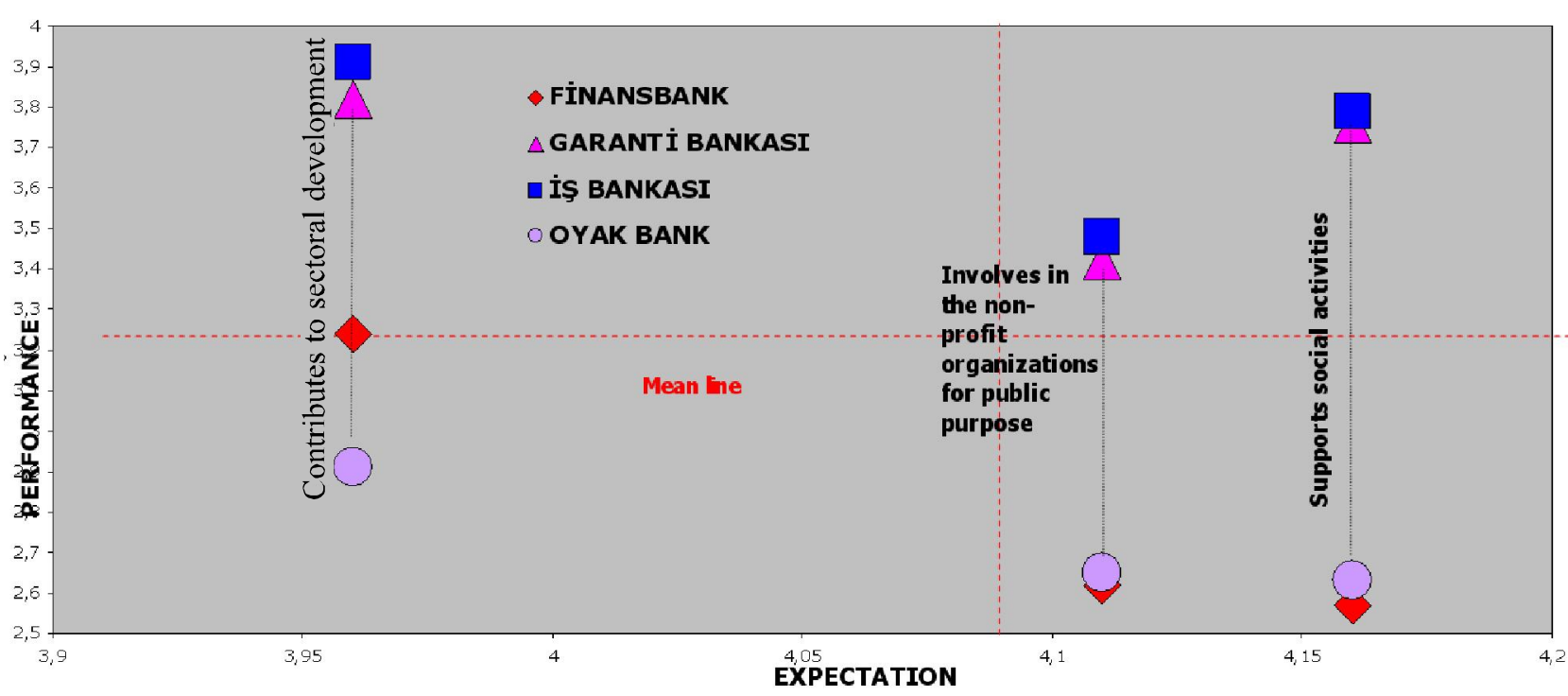


Table 5 .Figures for Product/Service Characteristics

\begin{tabular}{|l|r|r|r|r|r|}
\hline & EXPECTED & $\begin{array}{r}\text { FINANS } \\
\text { BANK }\end{array}$ & $\begin{array}{r}\text { GARANTI } \\
\text { BANKASI }\end{array}$ & $\begin{array}{r}\text { iş } \\
\text { BANKASI }\end{array}$ & $\begin{array}{r}\text { OYAK } \\
\text { BANK }\end{array}$ \\
\hline Keeping world standards in services & 4,37 & 3,32 & 3,70 & 3,80 & 2,72 \\
\hline Fast and correct services & 4,74 & 3,37 & 3,71 & 3,86 & 3,04 \\
\hline $\begin{array}{l}\text { Differentiated and creative } \\
\text { services for various segments }\end{array}$ & 4,26 & 3,24 & 3,66 & 3,89 & 2,69 \\
\hline A network of ATM and branch offices & 4,75 & 3,11 & 3,85 & 4,29 & 2,67 \\
\hline Reasonable transaction costs & 4,58 & 2,99 & 3,20 & 3,44 & 2,72 \\
\hline Reasonable credit terms and interest rates & 4,46 & 3,02 & 3,21 & 3,52 & 2,74 \\
\hline Effectiveness of telepnone banking & 4,19 & 3,17 & 3,96 & 3,76 & 2,77 \\
\hline Effectiveness of internet banking & 3,91 & 3,41 & 4,03 & 3,90 & 2,84 \\
\hline Effectiveness of branch banking & 4,47 & 3,28 & 3,70 & 3,85 & 2,83 \\
\hline Average & 4,41 & 3,21 & 3,67 & 3,81 & 2,78 \\
\hline
\end{tabular}

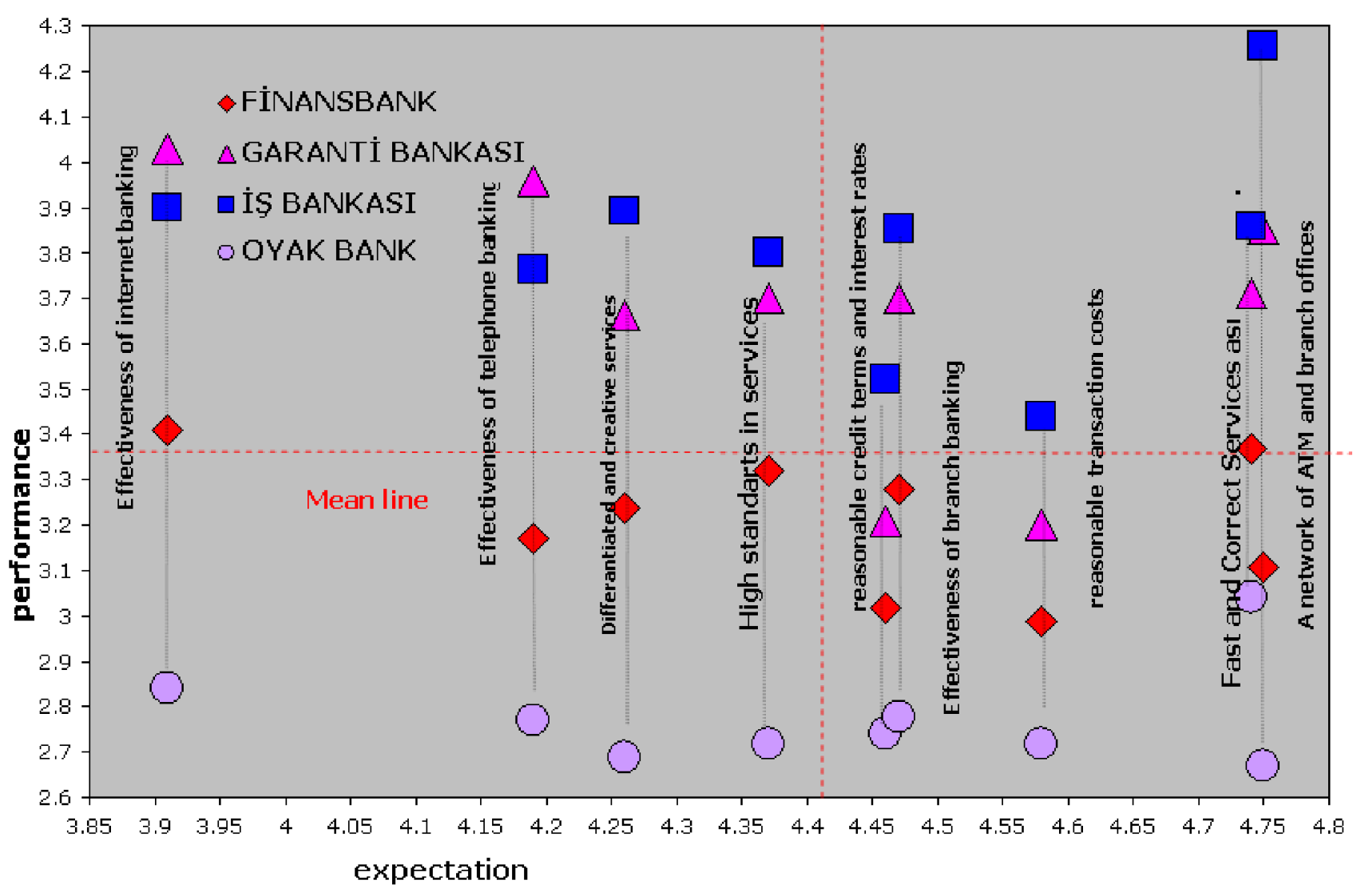


Table 6. Figures for Customer Relationship and Communication

\begin{tabular}{|l|r|r|r|r|r|}
\hline & EXPECTED & $\begin{array}{r}\text { FINANS } \\
\text { BANK }\end{array}$ & $\begin{array}{r}\text { GARANTİ } \\
\text { BANKASI }\end{array}$ & $\begin{array}{r}\text { ISS } \\
\text { BANKASI }\end{array}$ & $\begin{array}{r}\text { OYAK } \\
\text { BANK }\end{array}$ \\
\hline Customer satisfaction based activities & 4,65 & 3,27 & 3,70 & 3,72 & 2,81 \\
\hline Solving customer problems & 4,60 & 3,20 & 3,52 & 3,60 & 2,84 \\
\hline Appearing on local and international media & 3,74 & 3,31 & 3,66 & 3,80 & 2,87 \\
\hline Becoming a source of news in the field of banking & 3,96 & 3,24 & 3,66 & 3,75 & 2,98 \\
\hline Average & 4,24 & 3,26 & 3,64 & 3,72 & 2,88 \\
\hline
\end{tabular}

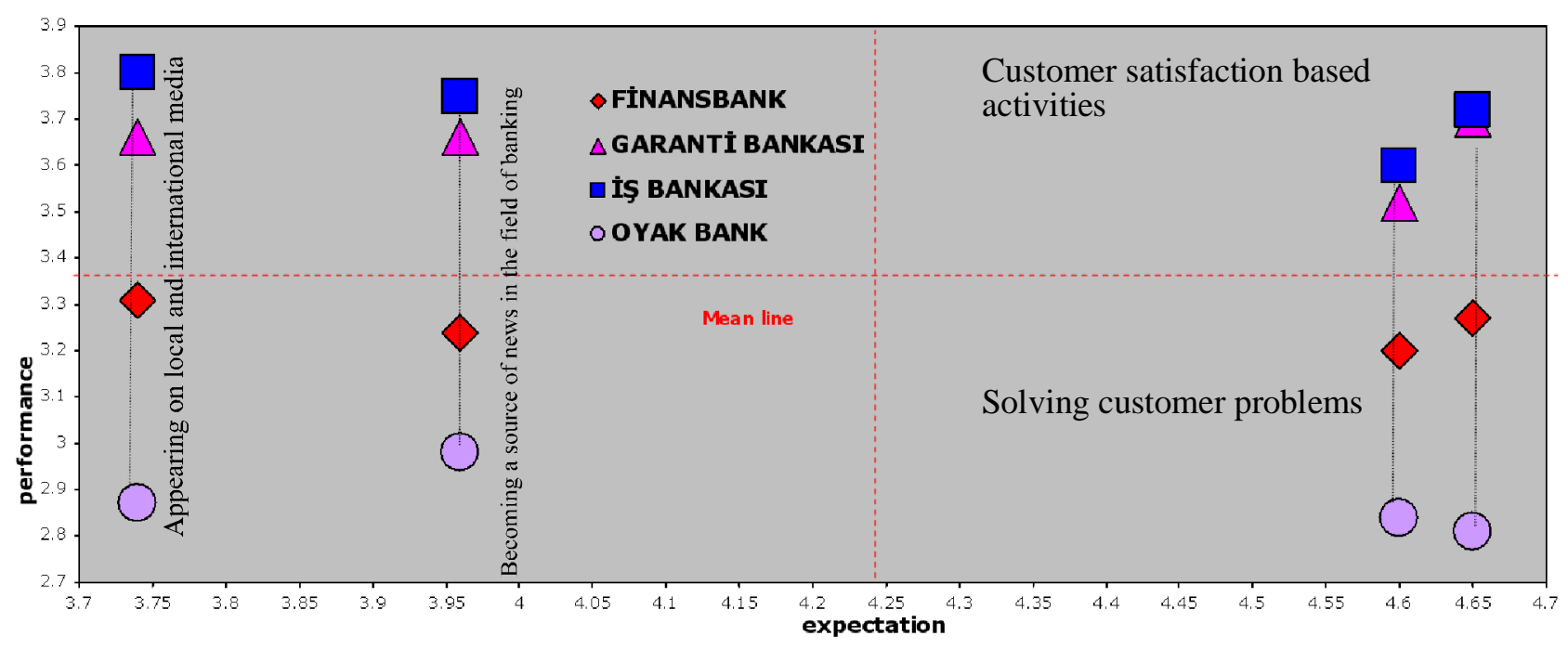




\section{REFERENCES}

Aaker, D.A., (1991), "Managing brand equity: Capitalizing on the value of a brand name", The Free Press, NY.

Aaker, D. A., (1990), "Brand extentions: The good, the bad, and the ugly", Sloan Management Review, 31(4); 47-56.

Aaker, D.A., (1996), "Measuring brand equity across products and markets", California Management Review, 38(3); 102-120.

Berry, L.L., (2000), "Cultivating service brand equity", Journal of the Academy of Marketing Science, 28(1), 128-137.

Berry, L.L., Seltman, K.D., (2007), "Building a strong services brand: Lessons from Mayo Clinic", Business Horizons, 50;199-209.

Chen, C., Chang; Y., (2008), "Airline brand equity, brand preference, and purchase intentions: The moderating effects of switching costs", Journal of Air Transport Management, 14; 40-42.

Doyle, P., (2003), DeğerTemelli Pazarlama, Media Cat yayınları.

Kapferer, J. N., (2004),"The New Strategic Brand Management: Ctreating and Sustaining Brand Equity Long Term", Kogan Page, London.

Keller, K.L., (1993), "Conceptualizing, measuring, and managing customer-based brand equity", Journal of Marketing, 57(1), 1-22.

Keth,H.T., Xie, Y., (2008), "Corporate reputation and customer behavioral intentions: The roles of trust, identification and commitment", Industrial Marketing Management, Article in press.

Knowles, J., (2008)," In search of a reliable measure of brand equity", www.zibs.com/knowles.shtml.

Kwun, D.J., Oh, H., (2007)," Comsumers'evaluation of brand portfolios", Hospitality Management, 26;8197.

Lee, J., Back, K., (2008)," Attendee-based brand equity", Tourism Management, 29(2); 331-344.

Milberg,S.J., Park, C.W., McCarty, M.S., (1997), Managing negative feedback effects associated with brand extentions: The impact of alternative branding strategies", Journal od Consumer Psychology, 6(2); 119-140.

Morgan, R., P., (2000), "A consumer-oriented framework of brand equity and loyalty ", International Journal of Market Research, 42(1); 65-78.
Netemeyer, R.G., and others, (2004), "Developing and validating measures of facets of consumer-based brand equity", Journal of Business Research, 57; 209224.

Pappu;R., Quester, P., (2006), "A consumer-based method for retailer equity measurement: Results of an emprical study", Journal of Retailing and Consumer Services, 2006; 317-329.

Salinas, E.M., Perez, J. M., (2008),"Modeling the brand extentions'influence on brand image", Journal of Business Research, article in pres.

Seggie, S.H., Cavusgil, E., Phelan, S.E., (2007), "Measurement of return on marketing investment: A conceptual framework and the future of marketing metrics", Industrial Marketing Management; 36; 834841.

Simon, C.J., Sullivan, M.W., (1993), "The measurements and determinants of brand equity,: A Financial approach", Marketing Science, 12(1); 2852.

Smith, E.,Bronner, F., Tolboom, M., (2007), "Brand relationship quality and its value for personal contact", Journal of Business Research, 60;627-633.

Weiss, A.M., Anderson, E. Macinnis, D.J., (1999),"Reputation management as a motivation for sales structure decisions", Journal of Marketing, 63(4); 74-89.

Yoo, B., Donthu, N., (2001),"Developing and validating a multi-dimensionnal consumer-based brand equity scale", Journal of Business Research, 52;1-14. 